\title{
The Success Of Chains: Customer Loyalty Or Customer Comfort?
}

Shelley M. Rinehart, University of New Brunswick Saint John

K. Doreen MacAulay (E-mail: dmacaula@unbsj.ca), University of New Brunswick Saint John

\begin{abstract}
The quest to understand customer behaviour has led researchers down many interesting paths. Is it satisfaction with the product, a feeling of belonging, a basic need, or perhaps something more? The literature lends itself to many theories and constructs that try to pin point what makes the consumer tick. Generally the literature defines both physical and psychological aspects of the consumer, that can help better predict the behaviour of the market. The research leaves many questions: Does one rely on the other? Are we measuring too much? Or are we missing the main points? This paper will look at the psychological aspect of the literature in trying to develop the Consumer Comfort construct (Spake, Beatty, Brockman and Crutchfield 2003), and to identify the basic determinates needed to measure buyer behaviour.
\end{abstract}

\section{Introduction}

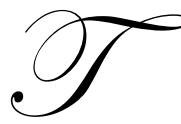

he growth of the service sector has been astounding over the past few years. On a global level, the service sector accounts for more than 50 percent of the gross national product (Bateson 1992). In the United States, total service sector sales, adjusted for inflation, and increased 26 percent between 1987 and 1992. During that same time period employment within the services sector increased by 20 percent resulting in an additional 3.2 million jobs and productivity of the workers increased by 5 percent (Du, Mergenhagen and Lee 1995).

Services sector dominance in the Canadian economy is even more dramatic. Over the past five years services have consistently accounted for more than 65 percent of Canadian GDP (Statistics Canada ${ }^{1}$ ) and have employed more than 70 percent of the Canadian workforce (Statistics Canada ${ }^{2}$ ). In fact, some believe that if current trends continue that, by the year 2025, almost every Canadian will be working gin the service sector (Grubel and Walker 1989).

Along with this intense growth comes a heavy reliance on the ability to measure service quality and to realize the role of service quality as a driver of repeat purchase behaviour.

\section{Literature Review}

\subsection{Consumer Evaluation Of Service Quality}

With the importance of service offerings being recognized, firms are also realizing the importance of being able to identify and meet service consumers' needs and wants. The challenge for the firm is that the manner in which consumers evaluate a traditional product purchase differs from the manner in which they evaluate the purchase of a pure service or the service component of a product purchase. According to Levitt (1980), service consumers typically do not know what they want or are getting until they do not get it.

Research supports the idea that the service evaluation process differs from that of traditional products. In fact, Zeithaml, Parasuraman and Berry (1992) identify four very distinct characteristics that set services apart from traditional product firms: intangibility, inseparability, heterogeneity and perishability. 
As a result of these differences, consumers are forced to use different methods to evaluate their satisfaction with the services received and, consequently, marketers are forced to provide different cues to ensure consumer satisfaction in the services setting. Within the services sector, the successful manipulation of consumer perceptions, based on consumer needs and wants, may play a more important role for creation of satisfied service consumers than for satisfied consumers of traditional, tangible products (Davidow 1988, Siehl, Bowen and Pearson 1992).

Perceptions of service quality and satisfaction evaluations have been found to be linked to consumer behaviour outcomes. Cronin and Taylor (1992) found that satisfaction had a strong and consistent impact on purchase intentions, as did perceived service quality to a lesser extent. Fornell (1992) notes that while "loyal customers are not necessarily satisfied customers... satisfied customers tend to be loyal customers" (p. 7). In times of increasing competitive pressure, the importance of developing a loyal customer base intensifies.

Given the importance of service quality and customer satisfaction with respect to purchase decisions a number of researchers have developed measurement tools which allow an assessment of service quality and provide information regarding the criteria on which consumers base their evaluations. This information is important to academicians and practitioners alike. The identification of these criteria are paramount to the understanding of the service evaluation process, either for the purpose of further study or to develop service offerings that are more effective in terms of meeting the needs and wants of the consumer.

\subsection{Measuring Service Quality}

A number of researchers have developed measurement tools for assessing service quality and, as with any measurement tools, some have proven more useful than others. The SERVQUAL scale, developed by Parasuraman, Zeithaml and Berry (1985), has proven to be one of the more popular and enduring of these measures. Since its development, SERVQUAL has gained wide scale acceptance and has proven to be a popular measurement tool with academicians and practitioners alike.

Parasuraman, Zeithaml and Berry (1985) identified five general areas that affect consumer assessments of service quality. They classified these factors as: tangibles - what the consumer comprehends; responsiveness - willingness and ability to provide prompt service; assurance - competence and courtesy direct toward increasing consumer confidence; empathy - caring attitude toward the customer which allows flexibility when circumstances warrant it; and reliability - the ability to do things right the first time.

They conceptualized service quality as a function of the measurement of differences between expectations and perceived actuality on measurements of these five constructs. The SERVQUAL scale is designed such that it measures both consumer expectations and assessments of actual service performance. Parasuraman, Zeithaml and Berry (1988) believed that this scale would not only provide an overall measure of service quality but would also enable service providers to identify areas where consumer expectations were not being met.

\subsection{SERVQUAL Concerns}

For years the service industry has relied on SERVQUAL as a tool to measure customer satisfaction and as a tool to predict customer satisfaction. From that data we often extrapolate the likelihood that a consumer will revisit a service provider based on their assessment of service quality and satisfaction. Those responsible for the development of SERVQUAL encourage researchers to explore the dimensions that constitute SERVQUAL and the nature of the relationships that may exist between them (Parasuraman, Berry and Zeithaml 1991). Since that time many have taken them up on their suggestion questioning everything from the number of dimensions, the accurate descriptor that encapsulates the essence of the dimension, as well as the applicability of the dimensions and the instrument outside of the services application.

Perhaps most interesting is the question regarding the stability of the five dimensions of the SERVQUAL Scale. While this topic has not yet received much attention in the literature, preliminary research results call the five-factor solution into question. Mels, Boshoff and Nel (1997) were unable to replicate Parasuraman, Zeithaml 
and Berry's (1988) five-factor solution. Instead they identified only two dimensions: intrinsic and extrinsic service quality. Intrinsic service quality is produced by human interaction during the service encounter and extrinsic service quality is based on the tangible aspects of service delivery. Babakus and Boller (1992), on the other hand, see service quality as a uni-dimensional construct.

\subsection{New Ideas}

Following through from the questions concerning dimension stability, come the introduction of new constructs that may provide a clearer linkage between consumer perceptions and consumer behaviour. In the most recent issue of the Journal of Service Research (Vol. 5(4); May, 2003) Spake, Beatty, Brockman and Crutchfield introduce the concept of consumer comfort. These researchers define comfort as having three primary components: physical, physiological and psychological. However, they choose to only focus on psychological comfort in their research seeing it as a primary factor in customer loyalty. Their research suggests that comfort has a "significant and incremental impact on satisfaction, trust, commitment and active voice with service providers". There results also suggest that comfort may be an intervening variable in the relationship between satisfaction and commitment.

It would appear that the psychological elements are the intangible factors in a customer's assessment of comfort. If comfort is indeed linked to satisfaction and commitment, both often sited as predictors of customer loyalty and repeat purchase behaviour, the question becomes: are consumers loyal to a brand name or a chain of service providers because they are satisfied or they are rewarded or is it because they have developed a sense of "comfort" based on consistency, reliability and/or predictability that has increased the perceived cost of switching behaviour. Does it really matter if it is McDonald's or Wendy's or the Hilton or the Sheraton or is the deciding factor the comfort one associates with a known national chain in comparison to a local, unknown provider?

Another entrant into the customer satisfaction dilemma is the construct of commitment. In Fullerton's (2003) study of commitment the construct is investigated using two components: continuance and affective commitment. Continuance commitment is a result of reliance and switching costs. Affective commitment is based on a fondness and identification with the good or service. The affective commitment creates an emotional attachment within the consumer found to have a positive affect on repeat purchase behaviour. The level of continuance commitment, however, impacts this purchase behaviour. If affective commitment is not present continuance commitment has a positive affect, however, if affective commitment is present continuance commitment can actual have an injurious effect. Literature reviewing customers' needs (Schneider \& Bowen 1999), sheds light on this reverse reaction through the investigation of three basic human needs: security, justice and self-esteem.

In recent years service organizations, in particular airlines and large hotel and food chains, have moved to loyalty programs to further develop their repeat client base through the development of relationships. Again, the belief is that the investment in rewarding relationship building and repeat behaviour is far surpassed by the benefits of retaining a stable customer base. The basis upon which these loyalty programs are built is that good service and the added benefits of rewards will heighten customer satisfaction levels thus encouraging repeat consumption. But what determines customer loyalty or repeat purchase behaviour? Can it be measured? How?

\section{Purpose}

The purpose of this paper is to present a framework for the further definition and examination of the constructs of service quality, commitment and consumer comfort, their respective dimensions and their role in the determination of repeat engagement of service providers. Initial data is presented questioning the validity of the five dimensional SERVQUAL construct. The relationship between the identified SERVQUAL dimensions and he constructs of commitment and comfort are examined and suggestions for future research endeavors made.

\section{Preliminary Results}

The first stage of this study involved the investigation of the stability of the dimensions of the SERVQUAL scale. For the purposes of this preliminary investigation, a sample of business students were asked to read a service 
encounter scenario describing one of four negative service outcomes; an incorrect fast food order, a lost text book, a missed exam or inaccurate advising. The subjects were then asked to fill out a SERVQUAL scale adapted to the scenario they had just read (See Appendix A). Four hundred and eleven useable surveys were obtained. While the authors acknowledge that the use of students as study subjects has been questioned a number of times in the literature, the service encounter scenarios used in this study are based on services typically patronized by university students. Due to the nature of the services studied, the use of student subjects is believed acceptable.

Examination of the scree plot suggested a three-factor solution as opposed to the five dimensions suggested by Parasuraman, Zeithaml and Berry (1988). The three dimensional solution was also supported by the results of the factor analysis. The decision criteria of no less than .50 for factor loadings were applied and only factors with eigenvalues of over 1 were considered.

Two questions loaded on more than one factor, and one question did not load significantly on any factor. Compared to the five dimensions suggested by Parasuraman, Zeithaml and Berry (1988)(tangibles (T), reliability $(\mathrm{RL})$, assurance (A), empathy (E) and responsiveness (RS)), the three factor solution appears to combine the assurance, responsiveness and empathy dimensions, leaving the tangibility and reliability dimensions relatively intact (see Table 1).

Factors two and three correspond to Parasuraman, Zeithaml and Berry's original reliability and tangibility dimensions respectively. Factor one, which combines the original assurance, empathy and responsiveness dimensions, may be better labeled as a "compassionate"

Table 1

Dimensionality Comparison

\begin{tabular}{|l|l|l|}
\hline \multicolumn{1}{|c|}{ Factor 1 } & \multicolumn{1}{|c|}{ Factor 2 } & \multicolumn{1}{|c|}{ Factor 3 } \\
\hline Q4 $(\mathrm{A})$ & Q2 $(\mathrm{RL})$ & $\mathrm{Q} 1(\mathrm{~T})$ \\
\hline Q5 $(\mathrm{E})$ & Q10(E) & Q6 (T) \\
\hline Q7 (RL) & Q11(RL) & Q14(T) \\
\hline Q8 (RS) & Q15(RL) & Q20(T) \\
\hline Q12(RS) & Q18(RL) & \\
\hline Q13(E) & & \\
\hline Q16(A) & & \\
\hline Q17(A) & & \\
\hline Q19(E) & & \\
\hline Q21(RS) & & \\
\hline
\end{tabular}
or "emotional" dimension. These results bear a striking resemblance to the findings of Boyt (1994). He also identified a three-factor solution consisting of tangibility, reliability and trust. This "combination factor" also bears a striking resemblance to general descriptions of the constructs of psychological comfort (Spake, Beatty, Brockman and Crutchfield 2003) and affective commitment (Fullerton 2003).

Looking first at comfort, as proposed by Spake, Beatty, Brockman and Crutchfield (2003), we see striking similarities between their definition of the construct and the factors which comprise the "combination factor" found in this study. Where comfort means "feeling at ease" and experiencing "reduced anxiety", the questions that cluster in factor 1 focus on confidence, willingness to help and individual attention. This leads then to the question; is comfort a new construct or has it always been a component of the traditional SERVQUAL scale? Further is the comfort construct actually a better predictor of consumer loyalty and repeat purchase behaviour than the metrics currently in place?

Similar comments are fitting when discussing the commitment construct as well. Where Fullerton (2003) defines commitment as "emotional attachment" and "fondness", the "combination factor" that emerged from the data in this study also shows these characteristics. Questions with emotional phrases such as "your best interests at heart" and "sincere interest in solving your problems" coupled with others that suggest a trust relationship, "tells you exactly when services will be performed" and "always willing to help you", bear a striking resemblance to the construct of commitment. Again, however, the important question remains: which is the better predictor of consumer loyalty and repeat purchase behaviour?

\section{Suggestions For Future Research}

There is no question that SERVQUAL as a metric requires further investigation. First, the stability of the previously identified dimensions needs to be reexamined. Perhaps of even more interest is the need to examine the ability of SERVQUAL and each of its component parts to predict customer satisfaction levels, loyalty and repeat 
purchase behaviours. At the same time the newly introduced constructs of commitment and comfort require the same scrutiny.

The next step for the authors is to test each of the three constructs within the hospitality service sector, namely food and beverage. The stability of the constructs and their metrics will be investigated. In addition relationships between the three constructs and their ability to predict customer loyalty and repeat purchase behaviour, on their own and in combination, will also be examined.

One cannot underestimate the value of such information. In an age where the services sector is growing in importance, any knowledge that can provide a competitive advantage is of value to the practitioner. From a theoretical standpoint, any research that helps us better understand the drivers of consumer behaviour are of the utmost value.

\section{References}

1. Babakus, E. \& Boller, G., “An Empirical Assessment of The SERVQUAL Scale,” Journal of Business Research," 24(3) (1992), 253-269.

2. Bateson, John E.G., Managing Services Marketing: Text and Readings, Texas: The Dryden Press, 1992.

3. Boyt, Thomas, A Study of Consumer Perception of Service Quality Based on Price, Outcome, and Information, Unpublished Doctoral Dissertation: Price College of Business, University of Oklahoma, 1994.

4. Cronin, J. \& Taylor, S., "Measuring Service Quality: A Reexamination and Extension," Journal of Marketing, 56 (1992), 55-68.

5. Davidow, W., "The Coming of Service Crisis," in C. Lovelock (ed.), Managing Services Marketing, Operations and Human Resources, (17-21), New Jersey: Prentice Hall, 1988.

6. Du, Fanglan, Mergenhagen, Paula and Lee, Marlene, (web page), "The Future of Services," American Demographics, http://www.demographics.com/publications/ad/95_ad/9511_ad/ad828.htm pp. 1-13.(1995).

7. Fornell, Claes, "A National Customer Satisfaction Barometer: The Swedish Experience," Journal of Marketing, 56 (1992), 6-21.

8. Fullerton, G., "When Does Commitment Lead to Loyalty?” Journal of Service Research, 5(4) (2003), 333344.

9. Grubel, Herbert G. and Walker, Michael, "Service Industry Growth," British Columbia: The Frasier Institute, 1989.

10. Levitt, Theodore, "Marketing Success Through Differentiation of Anything," Harvard Business Review, 58 (1980), 83-91.

11. Mels, Gerhard, Boshoff, Christo and Nel, Deon, "The Dimensions of Service Quality: The Original European Perspective Revisited," The Service Industries Journal, 17(1) (1997), 173-189.

12. Parasuraman, A., Berry, L. \& Zeithaml, V., "Refinement and Reassessment of SERVQUAL Scale," Journal of Retailing, 67(4) (1991), 420-450.

13. Parasuraman, A., Zeithaml, V. and Berry, L,. "SERVQUAL: A Multiple-Item Scale for Measuring Consumer Perceptions of Quality," Journal of Retailing, 64(1) (1988), 12 - 40.

14. Parasuraman, A., Zeithaml, V. \& Berry, L., “A Conceptual Model of Service Quality and Its Implications For Future Research," Journal of Marketing, (Fall 1985), 41-50.

15. Schneider, B., \& Bowen, D. E., "Understanding Customer Delight and Outrage," Sloan Marketing Review, 41 (1) (1999), 35-46.

16. Siehl, C., Bowen, D. \& Pearson, C., "Service Encounters As Rites Of Integration: An Information Processing Model," Organization Science, 3 (1992), 637-555.

17. Spake, D.F., Beatty, S.E., Brockman, B.K. \& Crutchfield, T.N., "Consumer Comfort in Service Relationships," Journal of Service Research, 5(4) (2003), 316-332.

18. Statistics Canada ${ }^{1}$ http://www.statcan.ca/english/pgdb/economy/economic/econ41.htm.

19. Statistics Canada ${ }^{2}$ http://www.statcan.ca/english/pgdb/economy/economic/econ40.htm.

20. Zeithaml, V., Parasuraman, A. \& Berry, L., "Problems and Strategies In Services Marketing," in J. Bateson (Ed.), Managing Services Marketing (48-67), Texas: The Dryden Press, 1992. 


\section{Appendix A}

\section{$\underline{\text { Instructions }}$}

The following set of statements relates to your feelings about the ***** Office in the College of Business at the University of Oklahoma. For each statement, please show the extent to which you believe the ***** office has the feature described by the statement. Use a scale from "1" to "7" where a "1" means that you strongly DISAGREE that the ***** office has that feature, and a "7" means that you strongly AGREE. Numbers between "1" and "7" represent more moderate levels of agreement or disagreement.

Record your level of agreement or disagreement for each statement in the space before each statement. There are no right or wrong answers.

1. $* * * * *$ has modern-looking office and service equipment.

2. When $* * * * *$ promises to do something by a certain time it does so.

3. Employees of $* * * * *$ give you prompt service.

4. The behaviour of employees of $* * * * *$ instills confidence in you.

5. $* * * * *$ gives you individual attention.

6. $* * * * * ' s$ physical facilities are visually appealing.

7. When you have a problem, $* * * * *$ shows a sincere interest in solving it.

8. Employees of $* * * * *$ are always willing to help you.

9. You feel safe in your transactions with *****.

10. ***** has operating hours convenient to all students.

11. ***** performs its services right the first time.

12. Employees of $* * * * *$ are never too busy to respond to your requests.

13. ***** has employees who give you personal attention.

14. Materials associated with the $* * * * *$ office (pamphlets, brochures) are visually appealing at the $* * * * *$ office.

15. ***** provides its services at the time it promises to do so.

16. Employees of $* * * * *$ are consistently courteous to you.

17. Employees of $* * * * *$ have the knowledge to answer your questions.

18. $* * * * *$ insists on error-free records.

19. $* * * * *$ has your best interests at heart.

20. $* * * * *$ 's employees are neat appearing.

21. Employees of ****** tell you exactly when services will be performed.

22. Employees of $* * * * *$ understand your specific needs. 